\title{
Online education at the medical School of Tongji University during the COVID-19 pandemic: a cross-sectional study
}

\author{
Yaxiang Song ${ }^{\dagger}$, Shu Wang ${ }^{\dagger}$, Yixian Liu, Xinying Liu ${ }^{*}$ and Ai Peng
}

\begin{abstract}
Background: The global reputation of coronavirus disease (COVID-19) has led universities in China to conduct online teaching. However, the actual feedback from medical teachers and students regarding online education remains unclear.
\end{abstract}

Methods: A prospective questionnaire survey examined the current opinions of online education from teachers and students at the Medical School of Tongji University.

Results: A total of 488 valid questionnaires were collected (223 males, 45.7\%; 265 females, 54.3\%), including 394 students (80.7\%) and 94 teachers (19.3\%). Most teachers and students were "in favor of online teaching," had "positive views for online education," were "satisfied with online teaching," and "expected for regular online education," although students thought that "too much learning tasks had been assigned" ( $90.4 \%$ teachers vs. $43.1 \%$ students, $P<0.001)$ and "less teaching effect than in offline classes" (68.1\% teachers vs. $43.4 \%$ students). Compared to female counterpart, male students had higher "learning interest" (27.6\% vs. $14.9 \%)$, "learning attention" (29.2\% vs. 14.4\%), "learning efficiency" (30.2\% vs. 16.7\%), and "better learning effect" (27.6\% vs. 15.3\%). Furthermore, male students had a significantly rise in attendance rate. Compared with male teachers, female teachers had less "experience in online educational course recording" (25.9\% vs. 50\%) and "past training for online teaching" (53.7\% vs. $77.5 \%$ ). Furthermore, they tended to be more "resistant to online teaching" (44.4\% vs. $22.5 \%$ ) and less "ready for online teaching" (70.4\% vs. 87.5\%). There was no significant difference in the acceptance of online teaching among teachers in different age groups.

Conclusions: Most teachers and students supported and were satisfied with the implementation of online education during the pandemic. Although teachers were less adaptable to online education, they still had positive opinions. Sex influenced the acceptance of online teaching. Male teachers and students showed better adaptability than their female counterparts. Although online teaching has advantages, it still cannot completely replace traditional offline teaching. As online education is a trend for future learning, universities should make more efforts to improve it, especially to provide more attention to female teachers and students.

Keywords: Medical students and teachers, COVID-19, Online teaching, Questionnaire, Prospective study

\footnotetext{
* Correspondence: liuxinying@tongji.edu.cn

${ }^{\dagger}$ Yaxiang Song and Shu Wang contributed equally to this work.

Center for Nephrology and Clinical Metabolomics and Division of

Nephrology and Rheumatology, Shanghai Tenth People's Hospital, Tongji

University School of Medicine, Shanghai 200072, People's Republic of China
}

(c) The Author(s). 2021 Open Access This article is licensed under a Creative Commons Attribution 4.0 International License, which permits use, sharing, adaptation, distribution and reproduction in any medium or format, as long as you give appropriate credit to the original author(s) and the source, provide a link to the Creative Commons licence, and indicate if changes were made. The images or other third party material in this article are included in the article's Creative Commons licence, unless indicated otherwise in a credit line to the material. If material is not included in the article's Creative Commons licence and your intended use is not permitted by statutory regulation or exceeds the permitted use, you will need to obtain permission directly from the copyright holder. To view a copy of this licence, visit http://creativecommons.org/licenses/by/4.0/ The Creative Commons Public Domain Dedication waiver (http://creativecommons.org/publicdomain/zero/1.0/) applies to the data made available in this article, unless otherwise stated in a credit line to the data. 


\section{Background}

The coronavirus disease of 2019 (COVID-19), transmitted mainly through the respiratory tract, has spread globally, and it has high morbidity and mortality [1]. To control the pandemic, the Chinese government has implemented strict prevention measures, such as prohibiting gatherings, closing schools, isolating people at home, and maintaining social distance [2]. Unlike face-to-face teaching, online classes are not restricted by geographic regions, so teachers and students can complete teaching tasks at home. The online teaching mode is thought to be an effective way in reducing the spread of infectious diseases in colleges by breaking chains of transmission $[3,4]$. Hence, Chinese colleges and universities have adopted online teaching practices [5].

Diversified online education can enrich learning and teaching methods $[6,7]$. Teaching management can be completed through network interactions, which are efficient and convenient $[8,9]$. Moreover, students could watch recordings of classes repeatedly offline. However, online teaching might weaken the supervision of students [10], and it is more common for students to skip classes and follow the lessons less carefully $[10,11]$. Besides, Mental health is another major problem [12]. Home segregation will cause anxiety and irritability due to limitation of activity space, lack of outside entertainment, worrying about health, and uncertainty about the future $[13,14]$. Therefore, as a new mode of teaching, online education still requires more research.

Online education in colleges and universities has been compulsory during the COVID-19 pandemic. However, the actual feelings and opinions of teachers and students are still unclear. Therefore, it is difficult for university administrators to take effective measures to improve it and guarantee the teaching effect. Thus, we investigated the status of online teaching in the medical school of Tongji University during the pandemic via an online questionnaire survey.

\section{Methods}

An online survey was conducted from March 24, 2020, to April 10, 2020. Self-designed questionnaires were distributed to teachers and students at the Medical School of Tongji University and were to be completed anonymously. All participants were aged $>18$ years. The teachers and students received the questionnaire via their social software accounts and were asked to complete it in 2 weeks, with repeated reminders during the valid period.

The questionnaire contained a total of 43 questions. Data were collected on age, sex, psychological state, opinions of online teaching, learning and teaching effects, and suggestions for online teaching in the future.

Questionnaire data with too short a response time $(<$ $2 \mathrm{~min}$ ) were excluded, as these questionnaires were thought completed without thinking and the data were unreliable. The same person could answer the questionnaire only once. All the data were imported into SPSS 24.0, and analyzed using the chi-squared test.

\section{Results}

\section{General information}

A total of 490 subjects responded, which included 488 valid questionnaires with a response rate of $100 \%$ and an effective rate of $99.6 \%$. There were 223 males (45.7\%) and 265 females (54.3\%), including 394 students (80.7\%) and 94 teachers $(19.3 \%)$. Among all the teachers, 39 $(41.5 \%)$ were aged $<40$ years. There was no statistical difference in the age ratio between male and female teachers, or in the number of students between sexes.

\section{Comparison of teachers' and students' opinions on online education}

There were no statistical differences between teachers and students in such aspects, including "in favor of online teaching," "positive views for online education," "satisfaction with online teaching," "expectation for regular online education," and "in favor of resource sharing among colleges." However, there were statistically significant differences in responses to questions such as "good communication in online class" (47.9\% teachers vs. $29.7 \%$ students, $P<0.05$ ), "good adaptation to online teaching" $(81.1 \%$ teachers vs. $89.8 \%$ students, $P<0.05)$, "too much learning tasks assigned than in offline teaching" (90.4\% teachers vs. $43.1 \%$ students, $P<0.001)$ and "ideal teaching effect of online education" (68.1\% teachers vs. $43.4 \%$ students, $P<0.05)$ (Table 1$)$.

\section{Comparison of opinions on online learning between male and female students}

Regarding online education, male students had a much greater increase in attendance rate (20\% vs. $10.1 \%)$, learning interest $(27.6 \%$ vs. $14.9 \%)$, and learning attention $(29.2 \%$ vs. $14.4 \%)$. In addition, male students had higher learning efficiency (30.2\% vs. $16.7 \%)$, better learning effect $(27.6 \%$ vs. $15.3 \%)$, more worries about study delay $(82.5 \%$ vs. $73.5 \%)$, and a greater sense of identity for too many learning tasks ( $54.6 \%$ vs. $34.6 \%$ ). There was no significant difference in the following aspects: "in favor of online teaching," "good communication in online learning," "satisfaction with teaching quality," "less exercise during online teaching," "irregular daily schedule," "anxiety moods," "spending extra time on electronic devices," and "slack in online class" $(P>0.05)$ (Table 2).

\section{Views of teachers across different sex and ages}

Female teachers had a lower proportion of votes regarding the following aspects: "resistance to online teaching" ( $44.4 \%$ vs. $22.5 \%)$, "ready for online teaching" $(70.4 \%$ vs. 
Table 1 Comparison of opinions on online teaching between teachers and students

\begin{tabular}{|c|c|c|c|c|}
\hline \multirow[t]{2}{*}{ Question } & \multicolumn{2}{|l|}{ Identity } & \multirow{2}{*}{$\begin{array}{l}\text { Total } \\
(\%) \\
N=488\end{array}$} & \multirow{2}{*}{$\begin{array}{l}P \text { - } \\
\text { value }\end{array}$} \\
\hline & $\begin{array}{l}\text { Student (\%) } \\
N=394\end{array}$ & $\begin{array}{l}\text { Teacher (\%) } \\
N=94\end{array}$ & & \\
\hline In favor of online teaching & $353(89.6)$ & $82(87.2)$ & $435(89.1)$ & 0.509 \\
\hline \multicolumn{5}{|l|}{ The views for online education } \\
\hline Only an emergency measure & $155(39.3)$ & $37(39.4)$ & $192(39.3)$ & 0.999 \\
\hline Supplement to offline teaching & $189(48.0)$ & $50(53.2)$ & $239(49.0)$ & 0.363 \\
\hline Replacement of offline teaching & $27(6.9)$ & $5(5.3)$ & $32(6.6)$ & 0.59 \\
\hline Good adaptation to online teaching & $354(89.8)$ & $77(81.1)$ & $431(86.5)$ & 0.017 \\
\hline Good communication in online class & $117(29.7)$ & $45(47.9)$ & $162(33.2)$ & 0.001 \\
\hline Too much learning tasks assigned than in offline teaching & $173(43.1)$ & $85(90.4)$ & $258(52.8)$ & $<0.001$ \\
\hline Ideal teaching effect of online education & $171(43.4)$ & $64(68.1)$ & $235(48.2)$ & $<0.001$ \\
\hline Satisfaction with online teaching & $243(61.7)$ & $53(60.7)$ & $209(61.5)$ & 0.625 \\
\hline Expectation for regular online education & $114(28.9)$ & $25(26.6)$ & $139(28.5)$ & 0.652 \\
\hline In favor of resource sharing among colleges & $246(62.4)$ & $66(70.2)$ & $312(63.9)$ & 0.158 \\
\hline
\end{tabular}

87.5\%), "past record experience" (25.9\% vs. 50\%), "past training for online teaching" (53.7\% vs. $77.5 \%)$, and "sparing more time on preparing online class" (59.3\% vs. 92.5\%) $(P<0.05)$. There was no significant difference in each question between teachers older or younger than 40 years old $(P>0.05)$ (Table 3$)$.

\section{Suggestions for future online teaching}

Teachers hoped to improve the function of live broadcast software $(70.2 \%)$, strengthen the management of online learning (69.2\%), make full use of current online resources (55.3\%), and upload supporting educational materials in time for the reference (34.0\%). Meanwhile, students hoped to optimize learning software (75.1\%), enhance online classroom experience (61.9\%), and raise learning consciousness (52.8\%). Both teachers (67.0\%) and students (59.1\%) anticipated constructing a resource-sharing system of online teaching among different schools.

\section{Discussion}

Online teaching was one of the Chinese government's initiatives to prevent and control the spread of COVID19. Our research showed that the majority of teachers and students in medical schools supported online teaching during the pandemic. This may be explained by the following findings: (1) online teaching was able to effectively prevent the infection of infectious diseases [3, 15]; (2) all the students and teachers were satisfied with and in favor of the government's anti-epidemic work [16, 17]; (3) online teaching could make the university teaching work advance as scheduled [18]; and (4) online teaching could relieve the anxiety of medical students about quarantine and exert a positive effect on their mental health $[19,20]$.
In the process of online teaching, most teachers and students could adapt to changes in teaching forms. Although teachers were relatively less capable of acclimatizing themselves to online teaching, they still believed online mode had an ideal teaching effect, which was higher than that of the student group. Because of intellectual deterioration and cognitive decline due to aging, elderly people may be slower to accept new things [2123]. However, teachers are more experienced and could be aware of the online teaching shortcomings and may accurately estimate its effect.

Interestingly, there were significant differences in the adaptability and learning status of online teaching between males and females in both teachers and students $(P<0.05)$. Thus, male teachers tended to be more adaptable to online teaching. Compared to female students, male students had a higher increase in learning interest, learning attention, attendance rate, and learning satisfaction. Males are generally more familiar with computers and are more easily adaptable to online teaching [24]. Females usually have more delicate emotions and place higher demands on themselves, which makes them more prone to stress [25] and feeling worried [26]. These personalities and characteristics pertaining to sex may partly explain these differences.

Interestingly, in the present study, we found that many more teachers thought online education had made them assign too many learning tasks. The reasons may be described as follows: (1) poor online communication between teachers and students [27]; (2) in teachers' opinion, students might have relatively low learning efficiency during home isolation [28, 29]; and (3) lack of initiative of students on learning due to learning more independently than offline education [30]. Therefore, during the epidemic period, while improving students' 
Table 2 Learning effect of students regarding online learning (male vs. female)

\begin{tabular}{|c|c|c|c|c|}
\hline \multirow[t]{2}{*}{ Item } & \multicolumn{2}{|l|}{ Sex } & \multirow{2}{*}{$\begin{array}{l}\text { Total } \\
(\%) \\
N=394\end{array}$} & \multirow{2}{*}{$\begin{array}{l}P \text { - } \\
\text { value }\end{array}$} \\
\hline & $\begin{array}{l}\text { Male (\%) } \\
N=183\end{array}$ & $\begin{array}{l}\text { Female (\%) } \\
N=211\end{array}$ & & \\
\hline \multicolumn{5}{|l|}{ The most concerned questions } \\
\hline Delay in study & $151(82.5)$ & $155(73.5)$ & $306(77.7)$ & 0.031 \\
\hline Anxiety moods & $132(72.1)$ & $144(68.3)$ & $276(70.1)$ & 0.401 \\
\hline Irregular daily schedule & $83(45.4)$ & $97(46.0)$ & $180(45.7)$ & 0.903 \\
\hline Less exercise & $74(47.0)$ & 89 (43.6) & $163(41.4)$ & 0.726 \\
\hline In favor of online teaching & $158(86.3)$ & $195(92.4)$ & $353(89.6)$ & 0.791 \\
\hline \multicolumn{5}{|l|}{ Spending extra time on electronic devices } \\
\hline $1-3 h$ & $46(24.9)$ & $46(22.0)$ & $92(23.4)$ & 0.504 \\
\hline $3-5 h$ & $77(41.6)$ & $77(36.9)$ & $154(39.1)$ & 0.332 \\
\hline $5-7 \mathrm{~h}$ & $39(21.1)$ & $56(26.8)$ & $95(24.1)$ & 0.186 \\
\hline $7-9 h$ & $11(6.0)$ & $20(9.6)$ & $31(7.9)$ & 0.182 \\
\hline More time & $12(6.5)$ & $10(4.8)$ & $22(5.6)$ & 0.463 \\
\hline \multicolumn{5}{|l|}{ Attendance rate } \\
\hline Reduced & $24(13.0)$ & $11(5.2)$ & $35(8.9)$ & 0.007 \\
\hline Unchanged & $122(67.0)$ & $179(84.7)$ & $301(76.4)$ & $<0.001$ \\
\hline Rose & $37(20.0)$ & $21(10.1)$ & $58(14.7)$ & 0.005 \\
\hline Slack in online class & $63(34.1)$ & $67(32.1)$ & $130(32.8)$ & 0.674 \\
\hline Good communication in online class & $59(23.3)$ & $58(27.5)$ & $117(29.7)$ & 0.303 \\
\hline Better learning effect than offline education & $51(27.6)$ & $32(15.3)$ & $83(21.1)$ & 0.003 \\
\hline \multicolumn{5}{|l|}{ Learning interest in online class } \\
\hline Rose & $51(27.6)$ & $31(14.9)$ & $82(20.8)$ & 0.002 \\
\hline Unchanged & $90(48.7)$ & $124(59.3)$ & $214(54.3)$ & 0.034 \\
\hline Decreased & $44(23.7)$ & $54(25.8)$ & $98(24.9)$ & 0.638 \\
\hline \multicolumn{5}{|l|}{ Learning attention in online class } \\
\hline Rose & $54(29.2)$ & $30(14.4)$ & $84(21.3)$ & $<0.001$ \\
\hline Unchanged & $61(33.0)$ & $97(46.4)$ & $158(40.1)$ & 0.007 \\
\hline Decreased & $70(37.9)$ & $82(39.2)$ & $152(38.6)$ & 0.776 \\
\hline Better learning efficiency in class & $56(30.2)$ & $35(16.7)$ & $91(23.1)$ & 0.001 \\
\hline Too much learning tasks & $100(54.6)$ & $73(34.6)$ & $173(43.1)$ & $<0.001$ \\
\hline Satisfaction with teaching quality & $125(68.3)$ & $118(55.9)$ & $243(91.7)$ & 0.051 \\
\hline
\end{tabular}

learning autonomy, teachers should try to communicate more with students and coordinate the amount of learning tasks.

Our study showed that the advantages of online education for medical students included the following: (1) reducing the risk of COVID-19 infection caused by population flow, while making teaching tasks be carried out during quarantine; (2) through course playback and courseware sharing, students can flexibly arrange their study time. However, the disadvantages of online teaching included the following: (1) objective long distance limited the interaction between teachers and students, influenced teachers' personal style and students' attention in class, and made the students' learning more difficult to manage; and (2) long-term use of electronic products could damage eyesight and health. Hence, online teaching cannot completely replace traditional teaching as a temporary alternative. These findings were similar to those in online teaching studies conducted in other majors [31], which indicates that the combination of online and offline teaching may become a new normal for medical education in the future.

Due to the short preparation time and heavy teaching tasks, there were many problems in the implementation of online teaching during the epidemic. The following solutions might be helpful: (1) making full use of the 
Table 3 Online teaching status of teachers

\begin{tabular}{|c|c|c|c|c|c|c|}
\hline \multirow[t]{2}{*}{ Item } & \multicolumn{2}{|l|}{ Age Group } & \multirow{2}{*}{$\begin{array}{l}P \text { - } \\
\text { Value }\end{array}$} & \multicolumn{2}{|l|}{ Sex } & \multirow{2}{*}{$\begin{array}{l}P \text { - } \\
\text { Value }\end{array}$} \\
\hline & $<40(\%) N=39$ & $\geqq 40(\%) N=55$ & & Male (\%) $N=40$ & $\begin{array}{l}\text { Female (\%) } \\
N=54\end{array}$ & \\
\hline Resistance to online teaching & $8(20.5)$ & $5(9.1)$ & 0.106 & $9(22.5)$ & $24(44.4)$ & 0.031 \\
\hline Past record experience & $14(35.9)$ & $20(36.4)$ & 0.963 & $20(50.0)$ & $14(25.9)$ & 0.016 \\
\hline Awareness of the meaning of online teaching & $23(59.0)$ & $37(67.3)$ & 0.409 & $30(75.0)$ & $30(55.6)$ & 0.052 \\
\hline Ready for online classes & $30(76.9)$ & $43(78.2)$ & 0.885 & $35(87.5)$ & $38(70.4)$ & 0.049 \\
\hline Past training for online teaching & $26(66.7)$ & $34(61.8)$ & 0.63 & $31(77.5)$ & $29(53.7)$ & 0.018 \\
\hline Adaptation to the online teaching & $30(76.9)$ & $47(85.5)$ & 0.29 & $36(90.0)$ & $41(75.9)$ & 0.08 \\
\hline Sparing more time in preparing online class & $29(74.4)$ & $40(72.7)$ & 0.86 & $37(92.5)$ & $32(59.3)$ & $<0.001$ \\
\hline No influence on teaching enthusiasm & $26(66.7)$ & $40(72.7)$ & 0.527 & $29(72.5)$ & $37(68.5)$ & 0.585 \\
\hline Achievement of ideal goals & $27(69.2)$ & $36(83.6)$ & 0.701 & $30(75)$ & $33(61.1)$ & 0.127 \\
\hline
\end{tabular}

uploaded online courses to avoid wasting teaching resources by duplication of recording; (2) optimizing and integrating learning software to improve online learning experience; (3) strengthening the interaction between teachers and students in online courses; and (4) giving more attention to females, such as providing more training opportunities for online teaching to female teachers, enhancing the interest and enthusiasm of female students in online classes, and so on.

\section{Limitations}

First, all our questionnaire respondents majored in clinical medicine; therefore, the conclusion only represents their subjective feedback on online teaching. Second, our survey relied on respondents' online self-reporting. Although it is convenient to collect data, the subjective judgment of respondents may lead to recall bias and misclassification. To this end, we guaranteed anonymity and confidentiality to all interviewees to exclude untrue data as much as possible.

\section{Conclusions}

Most teachers and students in medical schools supported and were satisfied with the implementation of online teaching during the pandemic. Although teachers were less adaptable to online teaching than students, they still held positive attitude toward it and believed online teaching was more effective. Sex differences significantly affected the acceptance of online teaching. Although online teaching has unique advantages such as breaking the space limit and making learning time more flexible, its inherent defects of objective distance and less direct communication make it impossible to replace traditional teaching at present. However, online education is still a trend for future learning, and universities should make more effort to improve it.
Acknowledgments

Not applicable.

Authors' contributions

Xinying Liu and Ai Peng designed the questionnaire. Yaxiang Song and Shu Wang were the major contributors in writing the manuscript. Shu Wang coordinated the study. Yixian Liu collected and analyzed the data. All authors read and approved the final manuscript.

\section{Funding}

Not applicable.

Availability of data and materials

All data generated or analyzed during this study are included in this published article.

\section{Declarations}

Ethics approval and consent to participate

All methods were carried out in accordance with relevant guidelines and regulations. All experimental protocols were approved by the ethnic committee of Shanghai Tenth People's Hospital. Informed consent was obtained from all subjects.

Consent for publication

Not applicable.

Competing interests

The authors declare that they have no competing interests.

Received: 6 May 2021 Accepted: 15 September 2021

Published online: 28 September 2021

References

1. Sohrabi C, Alsafi Z, O'Neill N, Khan M, Agha R. World Health Organization declares global emergency: a review of the 2019 novel coronavirus (COVID19). Int J Surg. 2020;76:71-6.

2. Wang C, Horby PW, Hayden FG, Gao GF. A novel coronavirus outbreak of global health concern. Lancet. 2020;395(10223):470-3.

3. Luca GD, Kerckhove KV, Coletti P, Poletto C, Bossuyt N, Hens N, et al. The impact of regular school closure on seasonal influenza epidemics: a datadriven spatial transmission model for Belgium. BMC Infect Dis. 2018:18:29.

4. Kawano S, Kakehashi M. Substantial impact of school closure on the transmission dynamics during the pandemic flu H1N1-2009 in Oita, Japan. PLoS One. 2015;10:e01448392.

5. COVID-19 infection leading group office should be handled by the Ministry of education on guiding the organization and management of online teaching in ordinary colleges and universities during the period of epidemic prevention and control (Higher Education Hall No. 2020). People's Republic of China Ministry of education, Accessed 20 May 2020. 
6. Muller M, Duperret S, Viale JP. E-learning in medicine: appraisal and perspectives. Example of an educational website about echocardiography in anaesthesia, intensive care and emergencies: www.echorea.org. Ann Fr Anesth Reanim. 2008;27(10):832-9.

7. Mooney G, Bligh J. Information technology in medical education: current and future applications. Postgrad Med J. 1997;73(865):701-4.

8. Nieto-Escamez FA, Roldán-Tapia MD. Gamification as online teaching strategy during COVID-19: a Mini-review. Front Psychol. 2021;12:648552.

9. Hilburg R, Patel N, Ambruso S, Biewald MA, Farouk SS. Medical education during the coronavirus Disease-2019 pandemic: learning from a distance. Adv Chronic Kidney Dis. 2020;27(5):412-7.

10. Sahu P. Closure of universities due to coronavirus disease 2019 (COVID-19): Impact on Education and mental health of students and academic staff. Cureus. 2020;12(4):e7541

11. Kearns LR. Student assessment in online learning: challenges and effective practices. MERLOT J Online Learn Teach. 2012;8:198.

12. Al-Rabiaah A, Temsah MH, Al-Eyadhy AA, Hasan GM, Al-Zamil F, Al-Subaie S, et al. Middle East respiratory syndrome-Corona virus (MERS-CoV) associated stress among medical students at a university teaching hospital in Saudi Arabia. J Infect Public Health. 2020 May;13(5):687-91.

13. Zhai $Y$, Du X. Mental health care for international Chinese students affected by the COVID-19 outbreak. Lancet Psychiatry. 2020;7:e22.

14. Reynolds DL, Garay JR, Deamond SL, Moran MK, Gold W, Styra R. Understanding, compliance and psychological impact of the SARS quarantine experience. Epidemiol Infect. 2008;136(7):997-1007.

15. Kawano S, Kakehashi M. Substantial impact of school closure on the transmission dynamics during the pandemic flu H1N1-2009 in Oita, Japan. PLoS One. 2015;10:e0144839.

16. Muniz-Rodriguez $K$, Chowell $G$, Cheung $C H$, Jia D, Lai PY, Lee $Y$, et al. Doubling time of the COVID-19 epidemic by Chinese Province. medRxiv. 2020; 2020.02.05.20020750. Update in: Emerg Infect Dis. 2020 Apr 24;26(8).

17. Ming WK, Huang J, Zhang CJP. Breaking down of healthcare system: mathematical modelling for controlling the novel coronavirus (2019-nCoV) outbreak in Wuhan, China; 2020. https://doi.org/10.1101/2020.01.27.922443. Accessed 20 May 2020

18. Ramnanan CJ, Pound LD. Advances in medical education and practice: student perceptions of the flipped classroom. Adv Med Educ Pract. 2017;8: 63-73.

19. Sreeramareddy CT, Shankar PR, Binu VS, Mukhopadhyay C, Ray B, Menezes RG. Psychological morbidity, sources of stress and coping strategies among undergraduate medical students of Nepal. BMC Med Educ. 2007;7:26.

20. Grubic N, Badovinac S, Johri AM. Student mental health in the midst of the COVID-19 pandemic: a call for further research and immediate solutions. Int J Soc Psychiatry. 2020;66(5):517-8.

21. McDougall GJ Jr. Cognitive interventions among older adults. Annu Rev Nurs Res. 1999:17:219-40.

22. Strittmatter A, Sunde U, Zegners D. Life cycle patterns of cognitive performance over the long run. Proc Natl Acad Sci U S A. 2020;117(44): 27255-61.

23. Singh-Manoux A, Kivimaki M, Glymour MM, Elbaz A, Berr C, Ebmeier KP, et al. Timing of onset of cognitive decline: results from Whitehall II prospective cohort study. BMJ. 2012;344:d7622

24. Bloise SM, Johnson MK. Memory for emotional and neutral information: gender and individual differences in emotional sensitivity. Memory. 2007; 15(2):192-204

25. Mota NP, Medved M, Wang J, Asmundson GJ, Whitney D, Sareen J. Stress and mental disorders in female military personnel: comparisons between the sexes in a male dominated profession. J Psychiatr Res. 2012;46(2):159-67.

26. Norton EJ, Georgiou I, Fung A, Nazari A, Bandyopadhyay S, Saunders KEA. Personal protective equipment and infection prevention and control: a national survey of UK medical students and interim foundation doctors during the COVID-19 pandemic. J Public Health. 2021;43(1):67-75.

27. Kyaw BM, Posadzki P, Paddock S, Car J, Campbell J, Tudor CL. Effectiveness of digital education on communication skills among medical students: systematic review and meta-analysis by the digital health education collaboration. J Med Internet Res. 2019;21(8):e12967.

28. Zimmermann $P$, Iwanski A. Emotion regulation from early adolescence to emerging adulthood and middle adulthood age differences, gender difference and emotion-specific developmental variations. Int J Behav. 2014; 38(31):182-94
29. Yuan J, Luo Y, Yan JH, Meng X, Yu F, Li H. Neural correlates of the females' susceptibility to negative emotions: an insight into gender-related prevalence of affective disturbances. Hum Brain Mapp. 2009;30(11):3676-86.

30. Crow J, Murray JA. Online distance learning in biomedical sciences: community, belonging and presence. Adv Exp Med Biol. 2020;1235:165-78.

31. Metzger MJ, Flanagin AJ, Zwarun L. College student web use, perceptions of information credibility, and verification behavior. Comput Educ. 2003; 41(3):271-90.

\section{Publisher's Note}

Springer Nature remains neutral with regard to jurisdictional claims in published maps and institutional affiliations.

\section{Ready to submit your research? Choose BMC and benefit from:}

- fast, convenient online submission

- thorough peer review by experienced researchers in your field

- rapid publication on acceptance

- support for research data, including large and complex data types

- gold Open Access which fosters wider collaboration and increased citations

- maximum visibility for your research: over $100 \mathrm{M}$ website views per year

At $\mathrm{BMC}$, research is always in progress.

Learn more biomedcentral.com/submissions 